This means that in hospital setting in case of infections caused by Klebsiella spp. a preferred choice would be either piperacillin/tazobactam or cefoperazone/sulperazone, or tigecycline. Employing carbapenems, ofloxacin/levofloxacin or doxycycline could allow us counting on a proper effect in slightly more than $50 \%$ of cases.

Conclusion. Developing the resistance in hospital environment microorganisms would have a significant impact on the treatment outcomes regarding patients with nosocomial

References

1. Sievert D. M., Ricks P., Edwards J. R., Schneider A., Patel J. et al. Antimicrobial-resistant pathogens associated with healthcare-associated infections: summary of data reported to the National Healthcare Safety Network at the Centers for Disease Control and Prevention, 2009-2010. Infect Control Hosp Epidemiol. 2013:34(1):1-14

2. Rudnov V. A., Belsky D. V., Dekhnich A. V. Infections at Emergency and Intensive Care Units (EICU): Results of National Multicenter Trial. Clin Microbiol Antimicrob Chemotherap. 2011;13(4):294-303.

EVALUATION OF KLEBSIELLA SPP. AND ACINETOBACTER SPP. ANTIBIOTIC RESISTANCE IN HOSPITAL ENVIRONMENT (STAVROPOL, RUSSIA) BATURIN V. A., SHCHETININ E. V., DEMIDENKO I. F., KUNITSINA E. A., KORABLEVA O. N.,

BATURINA M. V., KHARITONOVA Y.P.

Key words: Klebsiella spp., Acinetobacter spp., nosocomial infections infections. A bacteriologic monitoring of such microorganisms evaluating their resistance to a wide range of anti-microbial medications should be a mandatory activity not only in particular inpatient units yet in the region as a whole. This work would contribute both to the development of general standard requirements for empirical therapy of infections in hospitals and to establishing individual approaches when shaping the therapeutic tactics for particular patients.

3. Reshedko G. K., Ryabkova E. L., Krechikova O. I. Sukhorukova M. V., Shevchenko O. V. et al. Resistance to antibiotics for gram-negative causative agents of nosocomial infections at EICU in multifield hospitals of Russia. Clin Microbiol Antimicrob Chemotherap. 2008;10(2):163-179.

4. CLSI Performance standards for antimicrobial susceptibility testing; 21st informational supplement. 2011;(31):165

5. Evaluation of Microorganisms Sensitivity to Antibacterial Medications (Methodological Guidelines MUK 4.2.1890-04). Clin Microbiol Antimicrob Chemotherap. 2004;6(4):306-357.

ОЩЕНКА АНТИБИОТИКОРЕЗИСТЕНТНОСТИ

KLEBSIELLA SPP. И ACINETOBACTER SPP.

В СТАЦИОНАРАХ Г. СТАВРОПО ЯЯ

В. А. БАТУРИН, Е. В. ЩЕТИНИН, И. Ф. АЕМИАЕНКО

Е. А. КУНИЦЫНА, О. Н. КОРАБАЕВА,

М. В. БАТУРИНА, Я. П. ХАРИТОНОВА

Ключевые слова: Klebsiella spp., Acinetobacter spp., нозокомиальные инфекции

\title{
GENE POLYMORPHISM OF LIPID METABOLISM MARKERS IN CALCIFIC AORTIC VALVE DISEASE
}

\author{
Shcheglova E. V. ${ }^{1}$, Baikulova M. Kh. ${ }^{2}$, Boeva O. I. ${ }^{1}$, Laipanova A. I. ${ }^{2}$, \\ Chotchayeva Z. Kh. ${ }^{2}$, Khait G. Ya. ${ }^{1}$
}

\section{${ }^{1}$ Stavropol State Medical University, Russian Federation \\ 2 Regional Clinical Cardiology Center, Stavropol, Russian Federation}

Shcheglova Elena, MD, Assistant Professor, Department of Hospital Therapy, Stavropol State Medical University; +79034142734, e-mail: smets_82@mail.ru

Baikulova Madina, Cardiologist, Regional Clinical Center of Cardiology, Stavropol; e-mail: m.baykulova@mail.ru

Boeva Olga, MD, PhD, Professor, Department of Clinical Physiology, Cardiology and Introscopy, Stavropol State Medical University: e-mail: box0271@mail.ru

Laipanova Asiyat, Postgraduate Student, Department of Clinical Physiology, Cardiology and Introscopy, Stavropol State Medical University; e-mail: adzi777@mail.ru

Chotchayeva Zarema, Postgraduate Student, Department of Clinical Physiology, Cardiology and Introscopy, Stavropol State Medical University; e-mail: chotchaeva@yandex.ru alcific aortic valve disease (CAVD) (senile, degenerative aortic stenosis) is the process of thickening and calcification of aortic valve (AV) leaflets in the absence of rheumatic heart disease. In the cases of AV sclerosis (calcification) thickened leaflets don't impact normal intracardiac hemodynamics. Aortic stenosis is characterized by obstruction of the left ventricle outflow tract. Pathogenesis of calcific aortic valve disease involves lipid dismetabolism. [4]. A thorough analysis of the lipid profile in the CAVS patient population revealed increased levels of total cholesterol and athe- 
rogenic lipid fractions. It is interesting to note that the total cholesterol in these patients was higher than that of patients with coronary artery disease who underwent coronary bypass surgery [3]. However, only $40 \%$ of patients with calcific aortic stenosis (carotid angioplasty with stenting) have hemodynamically significant stenosis of the coronary arteries, and on the contrary in only $2 \%$ of patients with coronary artery disease, severe aortic stenosis is detected [1]. Apolipoprotein E (apoE) and paraoxonase 1 (PON1) regulate blood lipids levels being the mediators of lipids hydrolysis and oxidation. Increase of plasma levels of the above substances was observed in aortic valve calcinosis [5]. Perhaps allelic polymorphism of apoE and PON1 genes is responsible for CAVD formation.

The aim was to study the contribution of Leu28Pro polymorphism of apoE gene (rs429358) and Gln192Arg polymorphism of PON1 gene (rs662) to CAVD pathogenesis.

Material and Methods. Open non-randomized comparative case-control trial was performed. Objects were 100 patients (mean age $72.5 \pm 7.5$ years, $48.5 \%$ - men) with CAVD identified. Aortic stenosis was diagnosed in accordance with the recent international guidelines [2]. 46 controls without aortic valve calcification but with the similar profile of cardiovascular background, match for age, sex, the presence of coronary artery disease and treatment were included. The serum apoE and PON1 levels were determined by ELISA using AssayMax Human Apolipoprotein E ELISA Kit (Assaypro, USA) and Human serum paraoxonase 1 (PON1) ELISA Kit (Aviscera Bioscience Inc., USA) in accordance with the manufacturer's protocols. DNA was isolated from whole blood leukocytes using a DNA-sorb-C kit (Central Research Institute of Epidemiology, Federal Service on Customers' Rights Protection and Human Wellbeing Surveillance, Russia). In order to detect the

\section{References}

1. Chumakova O. S., Selezneva N. D., Evdokimova M. A., Osmolovskaya V. S., Kochkina M. S., Aseycheva O. Y., Minushkina L. O., Baklanova T. N., Talysin P. A., Tereshchenko S. N., Dzhaiani N. A., Akatova E. V., Glezer M. G., Galyavich A. S., Zakirova V. B., Kosiolova N. A., Polyanskaya E. A., Yagoda A. V., Boeva O. I., Khorolets E. V., Shlyk S. V., Volkova E. G., Rodicheva O. A., Levashov S. Y., Konstantinov V. O., Kalishevich N. B., Zateishchikov D. A. Prognostic value of aortic stenosis in patients after exacerbation of ischemic heart disease. Kardiol. 2011;51(1):23-28.

2. Galderisi M., Henein M. Y., D’Hooge J., Sicari R., Badano L. P., Zamorano J. L., Roelandt J. R. Recommendations of the European Association of Echocardiography:

\section{GENE POLYMORPHISM OF LIPID METABOLISM MARKERS IN CALCIFIC AORTIC VALVE DISEASE SHCHEGLOVA E. V., BAIKULOVA M. K., BOEVA O. I., LAIPANOVA A. I., CHOTCHAYEVA Z. K., KHAIT G. Y.}

Key words: apolipoprotein E, paraoxonase 1, lipids, aortic calcification, gene, polymorphism
Leu28Pro mutation in the apoE (rs429358) gene and the GIn192Arg mutation in the PON1 (rs662) gene, we used the corresponding reagent kits for revealing polymorphisms in the human genome by PCR with SNP-EXPRESS electrophoresis detection scheme (Research and Production Company Litekh, Russia)

Statistical analysis was performed using IBM SPSS Statistics 21 for Windows (IBM SPSS Inc., USA).

Results. The majority of patients in both groups were homozygous for the allel 28Leu of apoE (93\% - in CAVD and $96 \%$ - in controls, p>0.05), 1 patient with CAVD was homozygous for allel 28Pro, the rest were heterozygous. There was no difference in the prevalence of PON 1 allelic polymorphisms in the studied groups: Arg192Arg genotype was revealed in $60 \%$ of CAVD patients and $50 \%$ of controls, GIn192Arg genotype was revealed in $31 \%$ of CAVD cases and $43 \%$ of controls, and Gln192Gln genotype - in $9 \%$ и $7 \%$, respectively.

Allel 28Pro of apoE gene was associated with increased concentration of low density lipoproteins in patients with CAVD (3.9 \pm 1.05 vs $3.13 \pm 1.08 \mathrm{mmol} / \mathrm{l}$, $\mathrm{p}<0,02)$ and total cholesterol in controls $(6.2 ; 6.5$ vs $5.11 \pm 0.89 \mathrm{mmol} / \mathrm{l}, \mathrm{p} 0.05)$. PON1 genotype did not influence lipid metabolism parameters in CAVD. Controls with 192GIn allel demonstrated considerably decreased blood levels of total cholesterol (4.86 \pm 0.86 vs $5.5 \pm 0.87 \mathrm{mmol} / \mathrm{l}, \mathrm{p}<0.05)$, triglycerides $(1.41 \pm 0.69$ vs $1.86 \pm 0.6 \mathrm{mmol} / \mathrm{l}$, $\mathrm{p}<0.01)$, very low density lipoproteins $(0.64 \pm 0.31$ vs $0.85 \pm 0.27 \mathrm{mmol} / \mathrm{l}, \mathrm{p}<0.01)$ and apoE $(0.02$ $(0.02-0.03)$ vs $0.05(0.02-0.06) \mathrm{mcg} / \mathrm{l}, \mathrm{p}<0.01)$ and also increased PON1 serum concentration $(4,1$ (3.2-7.4) vs 3.3 (2.7-3.9) $\mathrm{mcg} / \mathrm{ml}, \mathrm{p}<0.01)$.

Conclusion. No association between GIn192Arg and Leu28Pro polymorphisms of PON1 and apoE genes respectively and CAVD was revealed. 28Pro allelic polymorphism of apoE gene was related to the increased blood levels of total cholesterol and low density lipoproteins in CAVD.

how to use echo-Doppler in clinical trials: different modalities for different purposes. Eur. J. Echocardiogr. 2011;12(5):339-353.

3. Novaro G. M., Pearce G. L., Sprecher D. L., Griffin B. P. Comparison of cardiovascular risk and lipid profiles in patients undergoing aortic valve surgery versus those undergoing coronary artery bypass grafting. J. Heart Valve Dis. 2001;10(1):19-24

4. Rajamannan N. M. Arterioscler. Calcific aortic stenosis: lessons learned from experimental and clinical studies. Thromb. Vasc. Biol. 2009; 29(2):162-168.

5. Yagoda A. V., Boyeva O. I., Shcheglova E. V., Baikulova M. H., Laipanova A. I. Aortic valve calcification: association with apoe and pon1 serum levels. Eur. J. Intern. Med. 2013;24(Suppl. 1):e23-e24.

\section{ГЕННЫЙ ПОАИМОРФИЗМ МАРКЕРОВ АИПИАНОГО МЕТАБОАИЗМА ПРИ КААЬЦИНИРУЮЩЕЙ БОАЕЗНИ АОРТААЬНОГО КААПАНА}

Е. В. ЩЕГАОВА, М. Х. БАЙКУАОВА, О. И. БОЕВА, А. И. ААЙПАНОВА, З. Х. ЧОТЧАЕВА, Г. Я. ХАЙТ

Ключевые слова: аполипоротеин Е, параоксоназа 1, липиды, аортальный кальциноз, ген, полиморфизм 